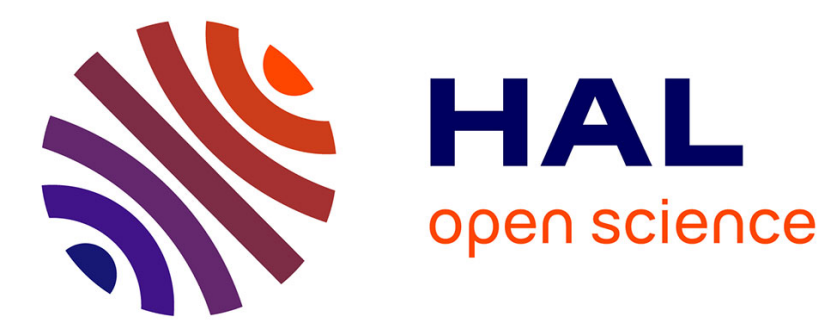

\title{
A Light Booth for Macro-Pictures
}

Oulfa Belhadj, Véronique Rouchon

\section{To cite this version:}

Oulfa Belhadj, Véronique Rouchon. A Light Booth for Macro-Pictures. Journal of Paper Conservation, 2015, pp.42 - 42. 10.1179/1868086015Z.00000000010 . hal-01447224

\section{HAL Id: hal-01447224 \\ https://hal.science/hal-01447224}

Submitted on 26 Jan 2017

HAL is a multi-disciplinary open access archive for the deposit and dissemination of scientific research documents, whether they are published or not. The documents may come from teaching and research institutions in France or abroad, or from public or private research centers.
L'archive ouverte pluridisciplinaire HAL, est destinée au dépôt et à la diffusion de documents scientifiques de niveau recherche, publiés ou non, émanant des établissements d'enseignement et de recherche français ou étrangers, des laboratoires publics ou privés. 


\title{
A Light Booth for Macro-Pictures
}

\author{
Oulfa Belhadj, Véronique Rouchon
}

Paper conservators often take pictures of their objects before and after treatment. Macro-pictures in particular are useful to monitor colour changes, removal of material, or ink diffusion possibly occurring on a millimetre scale. Their reliability however strongly depends on lighting reproducibility, which is not easy to achieve with conventional light booths. These are usually too large to appropriately monitor small-scale lighting. An alternative was found in a small light booth initially designed for machine vision lighting systems and capable to insure a good reproducibility of the light on a centimetre scale.

\section{Description}

The Lightune modular Dome Pack consists of a ring, a dome, and connector cable. The dome lighting is insured by an LED Ring of colour temperature $6500 \mathrm{~K}$ (white). The white dome diffuses light, allowing a uniform illumination of the area. Pictures are taken from a small hole on the top of the dome, measuring $2 \mathrm{~cm}$ in diameter. Before purchasing such

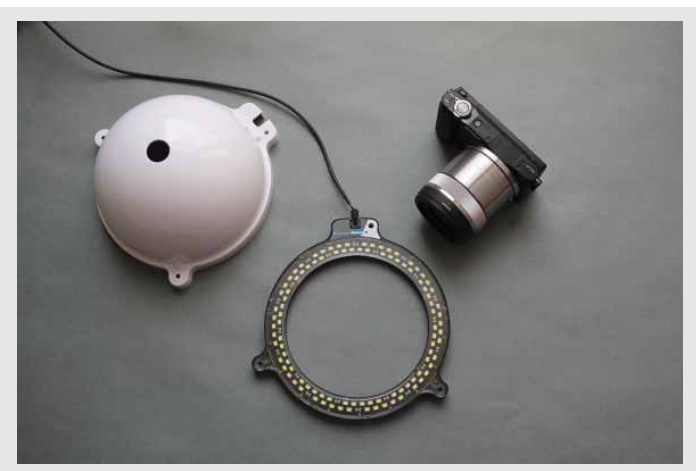

The dome, the ring, and the camera.

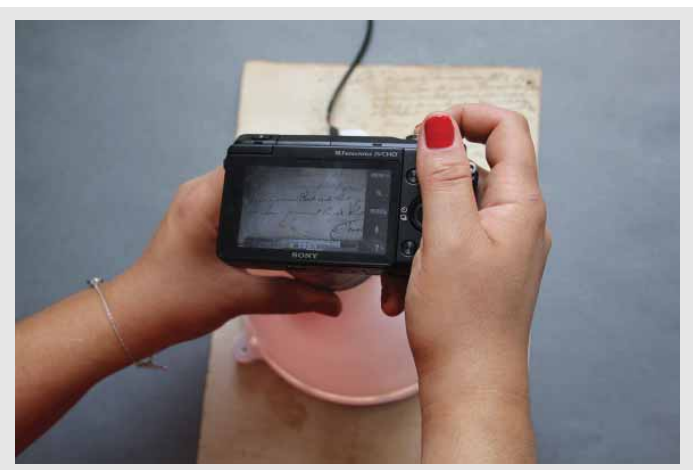

Align the camera with the aperture. a system, it is necessary to verify that the photo apparatus allows taking pictures through a $2 \mathrm{~cm}$ hole. It should additionally include a white balance option since LEDs provide discontinuous wavelength spectra.

\section{Supplier}

Lightune Europe, 20 rue de saint philbert, 44118 La Chevrolière, France, Tel +44 3300010 349,

http://www.lightune.com, contact@lightune.com

\section{Authors}

Oulfa Belhadj and Véronique Rouchon

CRC, 36 rue Geoffroy saint Hilaire, 75005 Paris, France, Tel +33140795300,

belhadj@mnhn.fr,rouchon@mnhn.fr

If you want to share information on new 'Materials \& Equipment' in the field of book and paper conservation, please contact Claire Phan Tan Luu or Dionysia Christoforou

claire.phantanluu@gmail.com,

d.christoforou@rijksmuseum.nl

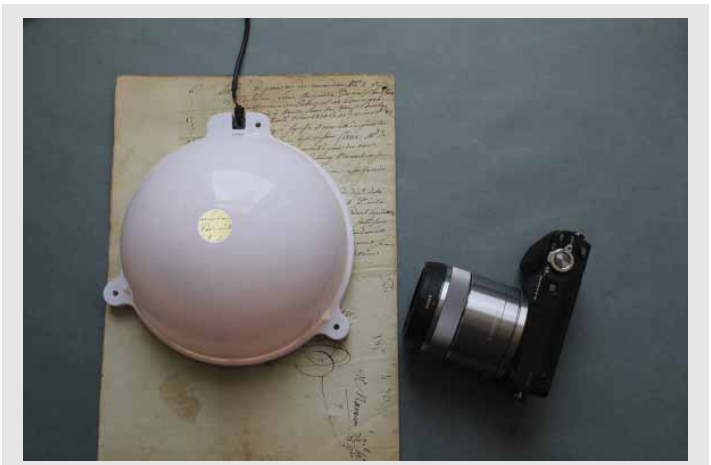

The dome can be directly placed on the object.

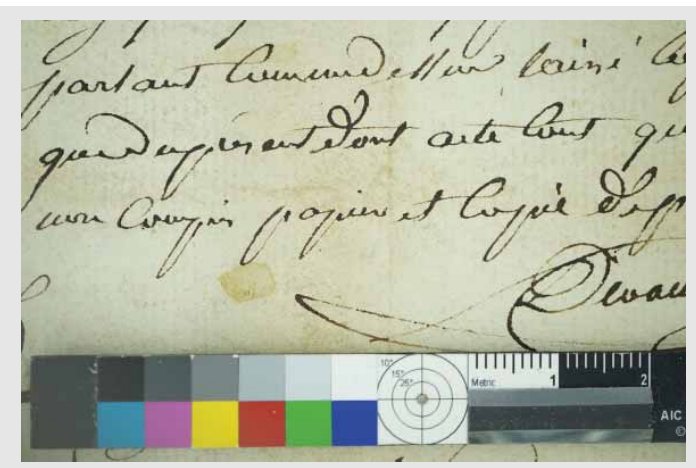

Example of a picture taken with the dome. 